\title{
Maps
}

1 The Frontier in Roman Britain 10

2 Southern Scotland AD 400-850 17

3 Scotland in the Time of Ptolemy 41

4 Northern and Central Scotland AD 550-850 102

\section{Genealogical Tables}

1 The British House of Rheged and Northumbrian Kings 22

2 Kings of the Strathclyde Britons 64

3 Kings of Dál Riata $\quad 178$

4 Kings of the Scots AD 850-1050 220 